\title{
PENINGKATAN KAPASITAS LEMBAGA MELALUI PENGEMBANGAN KOMUNIKASI PEMASARAN GUNA MENDORONG MINAT DONATUR DALAM BERDONASI PADA ISTANA YATIM DHU'AFA
}

\author{
Moh Farid Najib ${ }^{1}$, Deddy Saefuloh ${ }^{1}$, Iwan Mulyawan ${ }^{1}$, Eddy Syah Yahya $^{1}$, \\ Tjetjep Djatnika ${ }^{1}$ \\ ${ }^{1}$ Jurusan Administrasi Niaga, Politeknik Negeri Bandung \\ Email: : mohfaridnajib@polban.ac.id
}

\begin{abstract}
Abstrak
Istana Yatim Dhu'afa (Pesantren Alam Gratis Berbasis Agrobisnis) yang berlokasi di Jalan Sariwangi, Parongpong, Kabupaten Bandung Barat, Provinsi Jawa Barat, menghadapi permasalahan berupa belum memiliki donator tetap dan banyak calon donator yang kurang berminat untuk berdonasi karena Yayasan belum berbadan hukum, maka guna memenuhi kebutuhan pengelolaan para pengurus berjualan dan bercocok tanam demi menghidupi anak-anak asuhnya. Tujuan dari kegiatan ini adalah mengembangkan model komunikasi pemasaran yang dapat meningkatkan minat para donator untuk mendonasikan baik berupa infaq, shodaqoh maupun zakatnya. Kedua permasalahan tersebut adalah Istana Yatim Dhu'afa (Pesantren Alam Gratis Berbasis Agrobisnis) Hasil dari kegitan menunjukkan bahwa model komunikasi pemasaran yang dikembangkan berupa Instagram dan Facebook, disamping mengembangan logo baru yang dijadikan merek/barand bagi Yayasan sehingga mampu meningkatkan minat untuk berdonasi.
\end{abstract}

Kata kunci: Legalitas, kominikasi pemasaran, minat untuk berdonasi

\section{PENDAHULUAN}

Istana Yatim Dhu'afa merupakan suatu kesatuan dengan Pesantren Alam Gratis Berbasis Agrobisnis dan berlokasi di Jalan Sariwangi, Parongpong, Kabupaten Bandung Barat, Provinsi Jawa Barat. Istana Yatim Dhu'afa ini dirintis sejak tahun 2011 dengan diisiasi mengasuh 5 anak yatim (dhua'fa) dirumah pendiri, kemudian pindah ke Sariwangi Regency karena ada yang mewakafkan rumah untuk dijadikan panti asuhan, dan akhirnya di tahun 2014 mulai me- ngasuh dengan 19 anak dan memberi nama pada panti asuhan tersebut adalah "Istana Yatim Dhu'afa".

Konsep panti asuhan dengan pendidikan yang teritegrasi, melalui Pondok Pesantren dan Panti Asuhan dengan konsep tanpa dipungut biaya merupakan model konsep yang digunakan. Sampai dengan saat ini, Istana Yatim Dhu'afa mengasuh seketar 51 anak secara independent dan belum memiliki donator tetap. Sehingga untuk memenuhi kebutuhan sehariharinya para pengurus berjualan dan 
DIFUSI

Volume 3, No.1 Januari 2020

bercocok tanam demi menghidupi anakanak asuhnya. Sebagaimana ditunjukkan pada Gambar 1.

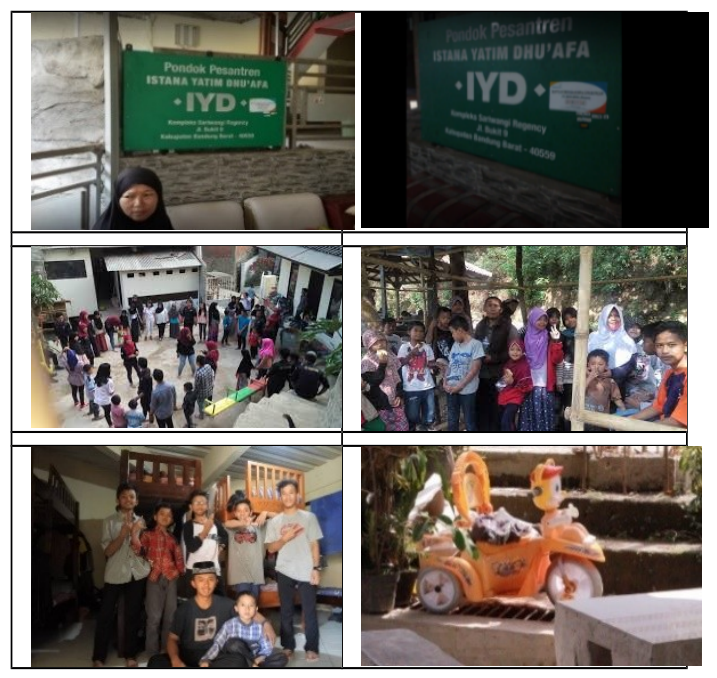

Gambar 1. Pondok Pesantren "Istana Yatim Dhu'afa"

Istana Yatim Dhu'afa merupan organisasi nir-laba (non-profit organization). Oleh kerena itu, pendapatan organisasi ini berasal dari masyarakat berupa donasi baik berupa infaq, shodaqoh dan zakat. Dari hasil in-depth interview dengan pengasuh Istana Yatim Dhu'afa (Pesantren Alam Gratis Berbasis Agrobisnis diberoleh beberpa informasi diantaranya; (1) pendanaan masih independen dan belum memiliki donator tetap dan banyak calon donatur; (2) donatur yang enggan berdonasi karena yayasan belum berbadan hukum tetap; (3) sehingga untuk memenuhi kebutuhan sehari-hari para pengurus berjualan dan bercocok tanam demi menghidupi anak-anak asuhnya. Namun demikian, legalitas kelembagaan Yayasan Istana Yatim Dhu'afa (Pesantren Alam Gratis Berbasis Agrobisnis) masih dalam proses melalui ke lembaga yang berwenang, namun hingga sekarang belum selesai.
Oleh karena, perlu proses penelusuran permasalahan yang dihadapi agar legalitas Yayasan segera selesai dan dapat menjadi daya tarik karena meningkatnya kepercayaan (trust) para donator yang akan mendonasikan baik infaq, shodaqoh maupun zakat-nya. Citra membentuk kepercayaan (trust), disamping itu informasi dapat pula membentuk kepercayaan (trust), selanjutnya kepercayaan dapat membentuk minat [1].

Pengembangan kepercayaan menjadi sangat penting, karena dapat meningkatkan minat donator untuk mendonasikan, sebagaimana dalam kontek organisasi secara umum, bahwa kepercayaan (trust) merupakan pondasi dari bisnis. Sebagaimana pada organisasi profit (perusahaan) bahwa dengan membangun kepercayaan pada pelanggan merupakan cara dalam menciptakan dan mempertahankan pelanggan. Dengan demikian dapat dikatakan bahwa kepercayaan merupakan elemen penting dari persepsi konsumen terhadap merek dan perusahaan [2]. Kepercayaan merupakan faktor yang dapat menguntungkan baik bagi pelanggan maupun perusahaan. Pelanggan akan mendapatkan keuntungan melalui persepsi pengurangan risiko terhadap penyediaan layanan dan melalui pemberian manfaat sosial yang berasal dari kepercayaan penyedia layanan tersebut, sementara perusahaan akan mendapatkan manfaat melalui peningkatan penjualan, penguruangan biaya, positive word-of-mouth dan bahkan retensi karyawan [3-4]. Demikian juga, membentuk kepercayaan pada organisasi nirlaba seperti Yayasan Istana Yatim Dhu'afa sangat diperlukan kepercayaan guna menjaga keberlanjutan. 
DIFUSI

Volume 3, No.1 Januari 2020

Disisi lain, pentingnya komunaksi kepada publik terutama untuk para donator, karena dapat memberikan informasi yang lengkap tentang Yayasan Istana Yatim Dhu'afa ini yang dampaknya dapat menarik minat mereka untuk mendonasikan baik berupa infaq, shodaqoh maupun zakat. Alat komunkasi yang dapat manarik minat ini dalam kontek bisnis dikenal dengan komunikasi pemasaran.

Seperti diketahui bahwa, pendapatan organisasi not for profit yang berasal dari masyarakat berupa donasi membutuhkan sebuah usaha pemasaran yang efektif agar masyarakat dapat mengenal organisasi tersebut [5]. Salah satu usaha organisasi untuk memperkenalkan organisasinya kepada masyarakat adalah melalui pemasaran, karena pemasaran merupakan suatu rangkaian kegiatan termasuk penjualan, penentuan-harga, riset-pasar, periklanan (advertising), hubungan-masyarakat (public-relations), promosi-penjualan (sales-promotion) dan direct-mail [6].

Donasi bagi organisasi not for profit merupakan salah satu tujuan dari pemasaran yang dilakukan. Organisasi non pemerintah dapat mencapai tujuan tersebut dengan memberikan kepuasan atas kebutuhan dari target pasar mereka [79].

Secara umum solusi permasalah tidak dapat dilakukan secara parsial, namun harus simultan. Oleh karena itu Gambar 1 menunjukkan desain solusi permasalahan Istana Yatim Dhu'afa, terhadap permasalahan-permasalahan yang dihadapi.

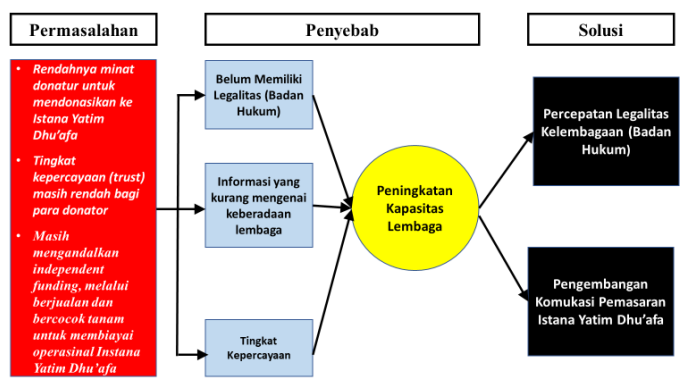

Gambar 1. Disain Solusi Permasalahan

Gambar 1 menunjukkan bahwa terdapat 2 (dua) alternatif penyelesaian permasalahan yang diajukan, yaitu; (1) Percepatan legalisasi kelembagaan (Badan Hukum); dan (2) Pengembangan Komunikasi Pemasaran.

\section{METODE}

\section{Desain Metode Pelaksanaan}

Desain Metode Pelaksaaan Solusi ini dikembangkan untuk mampu menjawab permasalahan yang dihadapi oleh Istana Yatim Dhu'afa, sebagaimana ditunjukkan pada Gambar 1 terdapat 2 solusi untuk menghadapi masalah rendahnya minat donator dalam mendonasikan baik berupa infaq, shodaqoh maupun zakat karena masalahan legalitas (badan hukum) dari Istana yatim Dhu'afa yang belum terbit, meskipun sudah diproses. Kedua, adalah berupa pengembangan model komunikasi pemasaran yang sesuai dengan kebutuhan dari Istana yatim Dhu'afa. Pada Gambar 2 ditunjukkan bahwa baik legalisasi kelembagaan maupun komunikasi pemasaran ditujukan untuk meningkatkan donatur dalam memberikan donasinya baik berupa infaq, shodaqoh maupun zakat. Pada solusi percepatan legalisasi kelembagaan akan dilakukan penelusuran proses agar dapat segera terbit keputusannya dari 
Kementerian Hukum dan Ham, secara rinci metode pelaksanaannya sebagai mana Gambar 2.

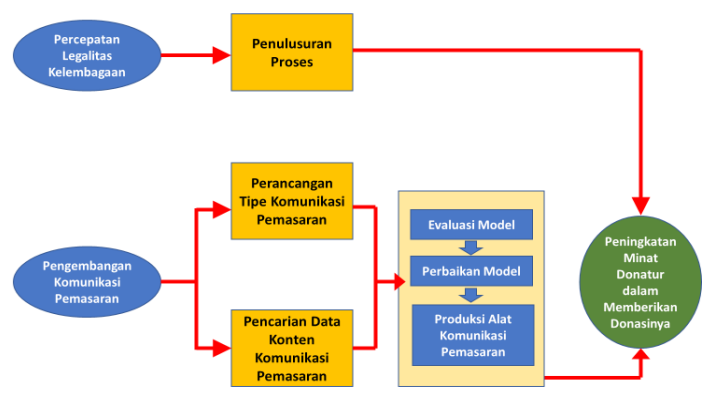

Gambar 2. Desain Model Pelaksanan Solusi Permasalahan

\section{Metode Pelaksanaan Legalisasi Kelembagaan}

Pendirian suatu Yayasan, baik itu Yayasan panti asuhan atau Yayasan lainnya sebagaimana telah diatur dalam undang-undang [10-11] bahwa dalam pendirian Yayasan sebagaimana tertuang pada pasal 9 ayat "(1) Yayasan didirikan oleh satu orang atau lebih dengan memisahkan sebagian harta kekayaan pendirinya, sebagai kekayaan awal; "(2) Pendirian Yayasan sebagaimana dimaksud dalam ayat (1) dilakukan dengan akta notaris dan dibuat dalam bahasa Indonesia; “(3) Yayasan dapat didirikan berdasarkan surat wasiat; “(4) Biaya pembuatan akta notaris sebagaimana dimaksud dalam ayat (2) ditetapkan dengan Peraturan Pemerintah; dan; "(5) Dalam hal Yayasan sebagaimana dimaksud dalam ayat (1) didirikan oleh orang asing atau bersamasama orang asing, mengenai syarat dan tata cara pendirian Yayasan tersebut diatur dengan Peraturan Pemerintah".

Oleh karena itu, perlu dilakukan dalam memonitor sampai sejauhmana proses legalisasi Yayasan tersebut telah berjalan, sehinga dengan Istana Yatim Dhu'afa yang berbadan hukum dalam bentuk Yayasan dapat meningkatkan kepercayaan (trust) donator. Sehingga tahapan yang perlu dilakukan beserta langkah-langkahnya, sebagaimana ditunjukkan pada Gambar 3.

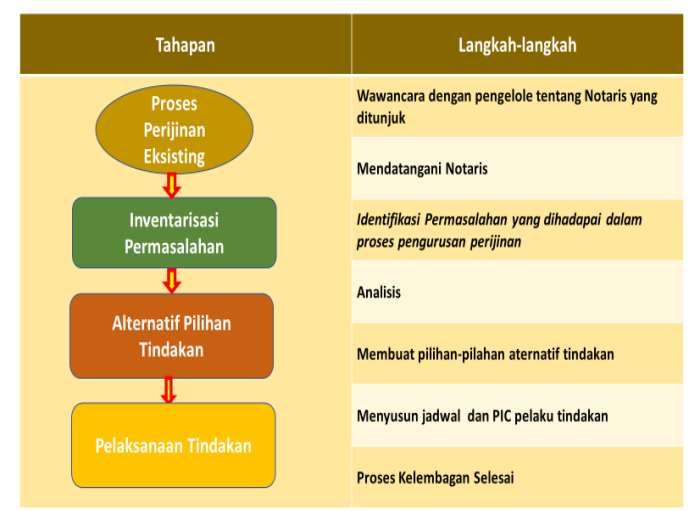

Gambar 3. Tahapan dan LangkahLangkah Penyelesaian Legalisasi Kelembagaan

\section{Metode Pelaksanaan Pengem- bangan Komunikasi Pemasaran}

Metode pelaksanaan pengembangan komunikasi pemasaran dilakukan melalui 4 (empat) tahap, yaitu :

a. Tahap pertama; analisis kebutuhan pengembangan dengan langkahlangkahnya adalah review analisi pengembangan dan analisis kebutuhan pengembangan;

b. Tahap kedua, yaitu perencanaan pengembangan kapasitas dan kapabilitas dengan langkah yang dilakukan adalah mencari bentuk pengembangan kapasitas dan kapabilitas yang selanjutnya dapat menghasilkan, perancangan tipe model komunikasi pemasaran dan pencarian data konten komunikasi pemasaran; 
c. Tahap ketiga, Uji coba model dengan langka-langkah berupa menganalisis alternatif model dan pengembangan draft tipe model; dan;

d. Tahap ke-empat, Implementasi model komunikasi pemasaran dengan langkah-langkah yang diawali dengan implementasi, kemudian evaluasi implementasi dan review perbaikan sebelum dilakukan produksi tipe model komunikasi pemasaran.

Tahapan-tahapan tersebut sebagaimana ditunjukkan pada Gambar 4.

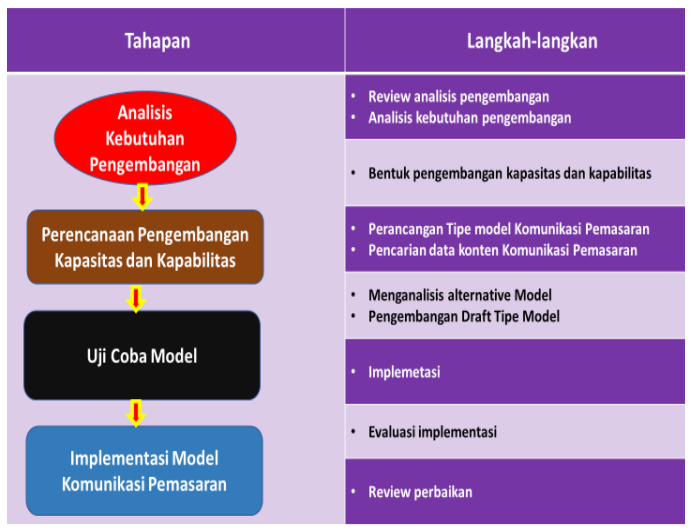

Gambar 4. Tahapan dan Langkah

Pengembangan Komunikasi Pemasaran

\section{HASIL DAN PEMBAHASAN}

Kegiatan pengabdian kepada masyarakat yang telah dilakukan meliputi 2 (dua) hal utama; yaitu; (1) percepatan legalisasi kelembagaan; dan; (2) pengembangan komunikasi pemasaran. Kedua kegitan tersebut dapat dijelaskan sebagai berikut.

\section{Hasil In-Depth Interview}

Hasil in-depth interview terhadap pengelola dan beberapa donatur eksisting, setelah dilakukan coding melalui kata- gori $5 \mathrm{~W}+1 \mathrm{H}$ (who, when, where, why, what, how), dapat disimpulkan sebagai berikut:

a. Kepercayaan terhadap legalitas kelembagaan dapat meningkatkan minat donatur untuk mendonasikan.

b. Informasi yang diperoleh berkaitan dengan keberadaan panti asuhan "Istana Yatim Dhuafa" diperoleh melalaui WoM (Word-of-Mouth) dari pengelola yang kebetulan adalah seoran Da'i/penceramah

c. Belum ada informasi lainnya baik berupa brochure, pamphlet, leaflet dan banner yang dapat dijadikan sumber informasi dan daya tarik serta minat untuk berdonasi.

d. Sumber dana diperoleh dari donatur melalui kegiatan pengajian, dan penjualan produk-produk hasil pertanian yang dikelola oleh panti asuhan.

\section{Pelaksanaan Legalitas Kelemba- gaan}

Tahapan dan langkah-langkah pelaksanaan percepatan legalitas kelembagaan, dimulai dengan dangan urutan-urutan sebagai berikut;

a. Proses perijinan eksisting. Langkah-langkah yang dilakukan dengan melakukan wawancara dengan pengelola tentang notaris yang ditunjuk. Dari hasil wawancara diperoleh informasi bahwa proses pengurusan kelembangan sudah ada donatur seorang notaris (tidak bersedia disebutkan namanya untuk sementara ini).

b. Inventarisir permasalahan. Langkah-langkah yang dilakukan berupa identifikasi permasalah yang diha- 
dapi dalam proses pengurusan perijinan. Hasil wawancara menunjukkan permasalahan yang dihadapi adalah masih ada nama yang sama yaitu Istana Yatim Dhu'afa telah ada. Oleh karena itu, diusulkan nama baru dengan masih mempertimbangan nama yang lama yaitu IYD. Nama baru yang diusulkan yaitu Pesantren Alam Gratis Berbasis Agrobisnis IYD.

c. Alternatif pilhan tindakan. Langkah-langkah yang dilakukan membuat pilihan-pilihan alternatif tindakan, namun karena sudah ditemukannya nama baru dan sedang dalam proses, maka tindakan ini tidak dilakukan.

d. Pelaksanaan tindakan. Langkalangkah yang dilakukan agar proses kelembagaan selesai pada saat ini sedang menunggu terbitnya Surat Keputusan dari Kementerian $\mathrm{Hu}-$ kum dan HAM.

Untuk lebih jelasnya proses kegiatan ini dapat dilihat dokumentasi foto-foto pelaksanaan kegiatan ini dengan langkahlangkahnya sebagaimana pada Gambar 5.

\section{Pelaksanaan Pengembangan Ko- munikasi Pemasaran}

Analisis kebutuhan pengembangan dibangun dengan menganalisis hasil survey untuk menghasilkan kebutuhan pengembangan model komunikasi pemasaran yang dapat meningkatkan minat para donatur untuk berdonasi di Istana Yatim Dhu'afa. Proses awal kebutuhan pengembangan meliputi:

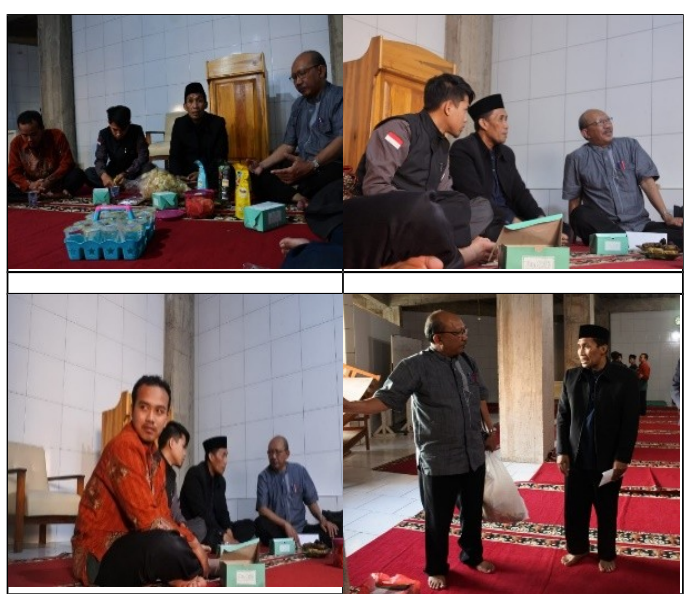

Gambar 5. Proses Wawancara Mendalam Berkaitan dengan Permasalahan dan Solusi yang telah dilakukan

a. Penggantian logo Istana Yatim Dhu'afa

Logo merupakan identitas suatu perusahaan yang implementasikan dalam berbagai bentuk visual seperti fasilitas sarana dan kegiatan dari suatu perusahaa. Logo dimanfaatkan sebagai lambang atau identitas diri dari suatu organisasi/badan usaha dan sebagai tanda pengenal ciri khas suatu organisasi/badan usaha dapat juga merupakan suatu simbol, dan atau tanda gambar, serta merekdagang (trademark) [12-14].

Citra merek (barand image) suatu perusahaan atau organisasi dapat dipengaruhi respon pelangan terhadap ketertarikan atas logo dan nama merek suatu perusahaan atau organisasi. Sebagaimana, Shimp [12] menyebutkan bahwa ketika pelanggan diminta untuk menyebutkan suatu merek tertentu, telah dianggap sebagai jenis asosiasi dalam membangun citra merek. Oleh karena 
itu, persepsi pelangan terhadap merek merepresentasikan pembentukan citra terhadap merek tersebut. Sehingga, dapat disimpulkan bahwa pelanggan yang memiliki persepsi positif terhadap citra suatu merek, akan lebih berimplikasi tehadap minat untuk melakukan pembelian [15].

Pengembangan logo perlu diperhatikan prinsip konstruksi/cirinya. Secara umum suatu logo yang baik akan memiliki ciri-ciri:

i. mudah dikenali dan juga untuk diingat kembali,

ii. membawa arti yang sama secara esensial untuk seluruh sasaran,

iii. perasaan positif timbul [12].

Dengan demikian, rancangan logo atau merek suatu perusahaan atau organisasi harus memenuhi kondisikondisi sebagai berikut;

i. kesesuaian dengan budaya menjadi suatu keharusan,

ii. menunjukkan sesuatu yang diinginkan dan mengambarkan keadaan yang sebenarnya,

iii. merupakan alat komunikasi visual.

iv. keseimbangan dalam pewarnaan,

v. irama dan proposi harus tergambarkan,

vi. harus artistik dan elegan serta sederhana akan tetapi memiliki penekanan yang terfokus, vii. keharmonisan rancangan,

viii. pengabungan antara tulisan dan/huruf yang sesuai dan tepat, agar pesan yang disampaikan diterima secara logis dan jelas [15].

Logo yang baik harus mempertimbangkan beberapa hal, [16] antara lain :

i. terdapat nilai kekhasan, unik dan terdapatnya pembedaan yang sangat jelas (original and desctinctive),

ii. mudah dibaca, meskipun ukuran dan media yang digunakan berbeda (legible),

iii. simpel dalam artian penangkapannya mudah dan dalam waktu yang relative singkat dapat dimengerti,

iv. mudah diingat (memorable),

v. jenis dan citra suatu organisasi/badan usaha mudah dihubungkan dan diasosiakan (easily associated with the compa$n y)$,

vi. mudah beradaptasi untuk semua media yang akan digunakan (easily adaptable for all graphic media).

Oleh karena itu, untuk meningkatkan minat para donatur melalui efektivitas komunikasi dan memudahkan untuk dikenal, maka Yayasan Istana Yatim Dhua'fa merubah logo lama dengan logo baru sebagaimana ditunjukkan pada Gambar 6. 


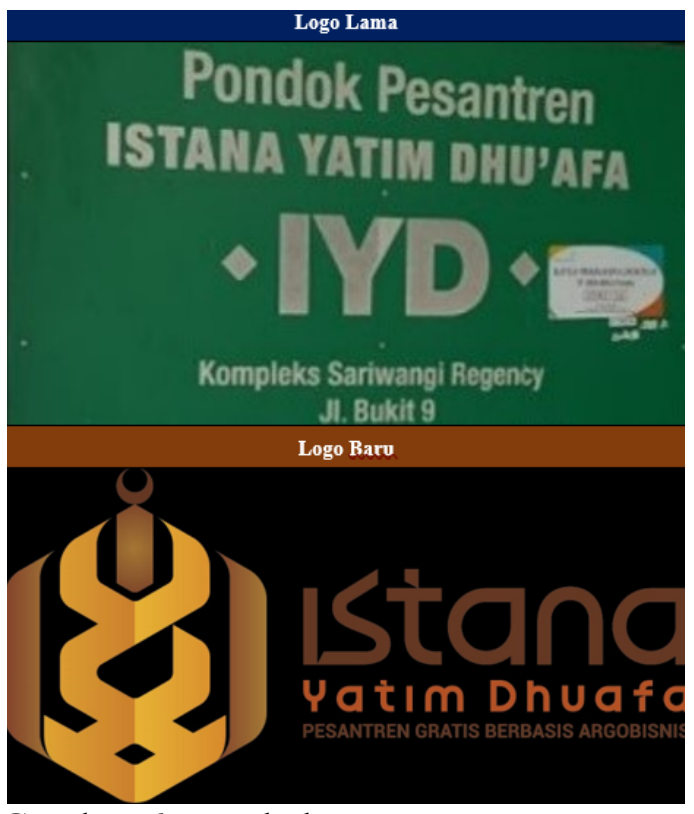

Gambar 6. Perubahan Logo Yayasan Istana Yatim Dhu'afa

b. Pengembangan Model Komunikasi Pemasaran

Pengembangan Model Komunikasi Pemasaran sesuai dengan konten yang ada dengan mempertahankan bentuk eksisting brosur yang ada ditambah dengan pengembangan Facebook Istana Yatim Dhu'afa dan Instagram Istana Yatim Dhua'fa.

Komunikasi pemasaran diakui memiliki hubungan yang erat dengan citra organisasi baik profit maupun non profit. Oleh karena itu, komunikasi pemasaran dapat dikatan baik apabila mencakup, unsur-unsur antara lain : periklanan (advertising), komunikasi-personal (personal communication), promosi-penjualan (sales promotion), publisitas dan hubungan masyarakat (publicity and publics relation), pemasaran-langsung (direct selling), dan pemasaran interaktif (interactives marketing)
[17]. Salah satu bentuk model yang sekarang banyak dipergunakan adalah pemasaran sosial media.

Sosial media dipersepsikan sebagai salah satu media yang tepat karena kemudahan dalam mengaksesnya [18]. Pengunaan sosial media merupakan langkah strategis dalam memasarkan suatu produk, sosial media tersebut dapat melalui; blog, social networking, facebook, dan instagram. Alasan penggunaan sosial media diakui mampu menurunkan biaya promosi, karena sosial media memiliki jangkauan luas dan memiliki kemudahan dalam mengakses dibandingkan dengan pemasaran konvensional [19-20]. Sosial media merupakan alat untuk berinteraksi baik berupa teks, gambar, video, maupun jaringan atara individu-individu dengan organisasi bisnis (konsumen dan produsen) [21-24]. Namun demikian, terdapat beberapa hambatan yang sering dijumpai oleh para pembisnis dalam pemanfaatan sosial media yaitu adanya terbatasnya kemampuan sumber daya manusia (SDM) dalam bidang teknologi informasi dan komunikasi [24-26]. Dengan demikian, perlu menjadi perhatian para pembisnis agar produk/layanan yang ditawarkan dapat diketahui oleh para pelanggan dimana saja.

Oleh karena itu, pada kesempatan saat ini sebagaimana hasil dari indepth interview akan dikembangkan beberapa model komunikasi pemasaran yang digunakan, yaitu brosur, instragram, dan facebook. Sedangkan 2 (dua) lagi model komunikasi 
pemasaran yang sedang dikembangkan berupa pemasangan papan nama dan pengembangan web-side. Kedua hal tersebut meskipun belum dikerjakan akan tetap dikerjakan meskipun kegiatan ini sudah berakhir.

Data pengguna media social memperlihatkan bahwa terdapat 7 (tujuh) sosial situs media yang populer pada tahun 2013, diantaranya; Facebook yang pertama, kemudian diikuti oleh Twitter, Google+, MySpace, LinkedIn, Friendster, dan yang terakhir Pinterest. Sementara itu, data jumlah pengguna internet di Indonesia mengalami peningkatan yang signifikan setiap tahunnya terus [27]. Kondisi ini terlihat dari grafik versi APJII (Asosiasi Penyelenggara Jasa Internet Indonesia) untuk periode tahun 1998-2012.

Sosial media berisi konten berbagai informasi, yang dimanfaatkan oleh siapa saja yang menggunakan teknologi. Sosial media sangat mudah untuk diakses dan dimanfaatkan sebagai fasilitator dalam berkomunikasi, mempengaruhi dan berinteraksi sesama dan dengan masyarakat umum [18]. Sementara, pemasaran yang menggunakan sosial media memungkinkan membentuk hubungan sosial yang lebih personal dan dinamis dibandingkan dengan strategi pemasaran tradisional. Oleh karena itu, aktivitas pemasaran melalui sosial media yang berpusat pada kegiatan untuk menciptakan kontenkonten yang aktraktif dan mengajak pembaca untuk berinteraksi serta menyebarluaskan dalam lingkungan jejaring yang dimilikinya. Dengan demikian, sosial media berbedabeda pengaruhnya. Namun demikian, secara umum yang terjadi adalah informasi yang berasal dari sosial berpengaruh terhadap minat untuk membeli.

Pertumbuhan penggunaan internet di Indonesia sangat tinggi, yaitu sebesar 51\% di tahun 2017. Pertumbuhan tersebut telah melampaui jauh dari angka pertumbuhan pengguna internet di dunia, yaitu sebesar $10 \%$, dengan demikian Indonesia menempati urutan ke dua pengguna internet terbesar. Dengan demikian dapat dikatakan bahwa 69\% lebih masyarakat Indonesia dengan perangkat mobile mereka mengakses internet. Sehingga, secara global telah melampaui penggunaan internet viamobile, yaitu sebesar $50 \%$.

Hasil survey terhadap pengguna internet di Indonesia adalah penduduk dengan berusia antar 16 sampai 64 tahun, dan menggambarkan bahwa masyarakat Indonesia secara akti menggunakan sosial-media sebagai platform mereka [29]. Platform tersebut terbagi kedalam 2 (dua) kategori sosial media, yaitu jejaring sosial media dan messenger. Selanjutnya, youtube dengan persentase penggunaan sebanyak $43 \%$, maka menduduki peringkat pertama, dan Facebook menduduki peringkat ke dua dengan persentase penggunaannya sebanyak $41 \%$, selanjutnya diikuti oleh Whatsapp (WA) dengan persentase penggunaan sebanyak $40 \%$, sebagaimana Gambar 7. 


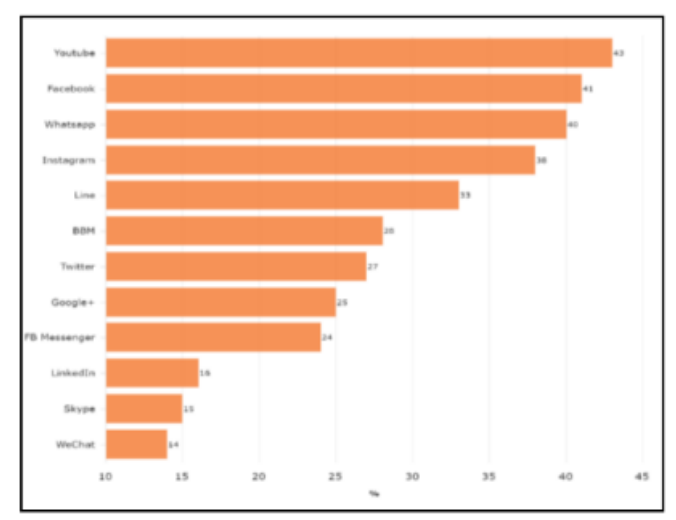

Sumber:https://databoks.katadata.co.id/datapublish/2018/02/01/m edia-sosial-apa-yang-paling-sering-digunakan-masyarakatindonesia

Gambar 7. Media Sosial yang Paling sering Digunakan di Indonesia (2007)

i) Facebook

Facebook adalah salah satu situs jejaring sosial berbasis web yang dibuat dengan tujuan untuk mendapatkan/mencari teman atau keluarga yang jarang ditemui. Namun sejalan dengan berkembang an teknologi dan meningkatnya pengguna, facebook, hingga saat ini pengguna facebook sudah mencapai sebanyak 65 juta orang [27].

Alasan seseorang menggunakan sosial media bebrbentuk facebook, karena sosial media ini diyakini hingga sekarang juga masih banyak yang menggunakannya, sehingga pihak Yayasan Istana Yatin Dhu'afa dapat melakukan branding melalui sosial media ini dan senantiasa mengupdate dengan informasi-informasi kegiatan yang dilakukan oleh Yayasan. Dengan demikian diharapkan mampu meningkatkan efektivitasnya melalu pe- ningkatan jumlah yang mengikuti (follow) dan jumlah yang menyukai (like), dari situ diharapkan akan muncul minat untuk berdonasi.

Untuk dapat masuk ke Facebook Yayasan Istana Yatim Dhu'afa, maka dapat mengujungi, https: $/ / \mathrm{m}$.facebook.com/istanayatimdh uafabandung/?

tsid $=0.2191230854929036 \&$ sour ce $=$ result.

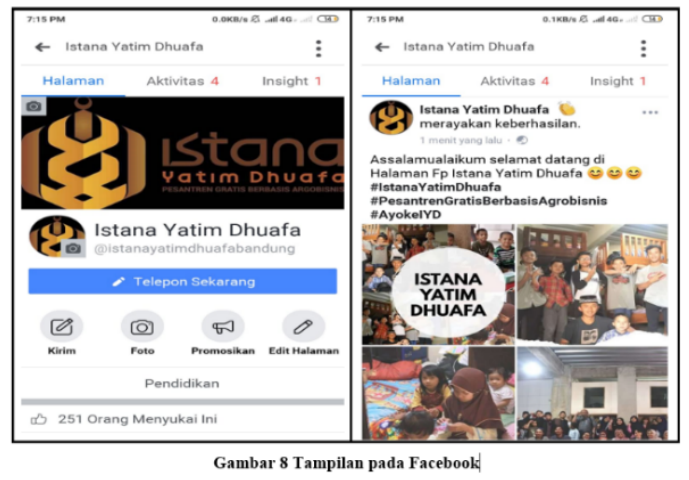

ii) Instagram

Instagran merupakan salah satu jenis sosial media yang terpopuler, dan biasa aplikasikan oleh beberapa orang guna mengabadikan kejadian-kejadian yang sangat berharga. Instagram pada awalnya hanya dapat dimangaatkan oleh pengguna saja, namun karena meningkatnya jumlah pengguna aplikasi ini, maka instagram merilis versi android dan windows phone. Oleh karena itu, dampaknya adalah pengguna instagram semakin banyak. Data jumlah pengguna Instagram diketahui bahwa jumlah pengguna instagram telah men- 
DIFUSI

Volume 3, No.1 Januari 2020

capai lebih dari 30 juta sampai dengan saat ini [27].

c. Akan dikembangkan lebih lanjut berupa alamat web, untuk komunikasi pemasaran memperbanyak sesuai dengan kebutuhan.

\section{KESIMPULAN}

Berdasarkan hasil dan pembahasan kegiatan Pengabdian Kepada Masyarkat ini dapat diketahui beberapa hal sebagai berikut:

1. Bagaimana meningkatkan minat para donatur untuk mendonasikan pada Yayasan Istana Yatim Dhu'afa, dari hasil in-depth interview terdapat beberapa pertimbangan yaitu; melegalkan kelembagaan dan proses ini sudah berjalan tinggal menunggu turunan surat keputusan dari Kementerian Hukum dan HAM.

2. Hasil analisis menunjukkan bahwa kebutuhan pengembangan model komunikasi pemasaran yang dapat meningkatkan minat para donatur untuk berdonasi di Istana Yatim Dhu'afa.

Proses awal kebutuhan pengembangan meliputi:

1. Mengganti logo Istana Yatim Dhu'afa

2. Pengembangan Model Komunikasi Pemasaran sesuai dengan konten yang ada dengan mempertahankan bentuk eksisting brosur yang ada ditambah dengan pengembangan Facebook dan Instagram Istana Yatim Dhu'afa dan Instagram Istana Yatim Dhua'fa; dan

3. Akan dikembangkan lebih lanjut berupa alamat web, untuk komuni- kasi pemasaran memperbanyak sesuai dengan kebutuhan. Namun demikian, model komunikasi pemasaran yang telah selesai adalah model sosial media melalui Facebook dan Instagram, sedangkan pengembangan web dan petunjuk arah menuju lokasi masih belum dikembangkan.

Sebagai simpulan yang dibuat di atas, maka dapat disarankan agar pengembangan model pemasaran nantinya mampu menarik minat para donatur untuk mendonasikan ke Yayasan Istana Yatim Dhu'afa, maka perlu dilakukan beberapa hal sebagai berikut:

1. Selalu mengukur tingkat efektivitas sosial media yang digunakan, berapa yang mengikuti, menyukai dan memberikan komentar atas postingan informasi dalam sosial media tersebut; dan

2. Mengembangkan model komunikasi pemasaran lainnya, seperti; personal selling (model ini dapat digunakan sekalian pihak Yayasan yang sering diundang untuk memberi tausiyah, dan pada kesempatan tersebsut mengingatkan para jamaah untuk berpartisipasi menyantuni anak yatim tersebut), cara lainnya mengembangkan web-site dan petunjuk arah menuju ke lokasi agar para donatur mudah untuk menuju ke lokasi.

\section{UCAPAN TERIMAKASIH}

Artikel ini hasil dari program kegiatan Pengabdian kepada Masyarakat terhadap panti Asuhan Yatim Dhu'afa (IYD) yang dibiayai oleh DIPA Politeknik Ne- 
DIFUSI

Volume 3, No.1 Januari 2020

geri Bandung sesuai dengan Surat Perjanjian Pelaksanaan Kegiatan No:439.4/PL1.R7 /PM/2019.

\section{REFERENSI}

[1] L. Lin dan C. Lu, The influence of corporate image, relationship marketing, and trust on purchase intention: the moderating effects of word-of-mouth. Tourism Review, 65(3), 16-34. 2010.

[2] J. L. Aaker, Dimensions of brand personality. Journal of Marketing Research, 34(3), 347-356. 1997

[3] C. Moorman, R. Deshpande, dan G. Zaltman, Factors affecting trust in market research relationships. Journal of Marketing, 57(1), 81101. 1993.

[4] P. H. Schurr dan J. L. Ozanne, Influence on exchange processes: Buyers' preconceptions of a seller's trustworthiness and bargaining toughness. Journal of Consumer Research, 11(4), 939-953. 1985.

[5] B. A. Weisbrod, The Non Profit Economy. Cambridge: Havard Universiti Press. 1998.

[6] P. R. Smith, Great answer to tough marketing questions. (E. Ahmadi, Trans.). Jakarta: Erlangga. 2001.

[7] D. Ackin, "Non profit Marketing: Just How Far Has It Comes?".NonProfit World, Vol 19 No.1, pp 3335. 2001.

[8] M. Tschirhart dan Bielefeld, Managing Nonprofit Organisation. San Fransisco: Jossey Bass. 2012

[9] Morisaan, Periklanan, Komunikasi Pemasaran Terpadu. Jakarta: Penerbit Kencana. 2014.

[10] Undang-Undang Republik Indonesia Nomor 16 Tahun 2001 tentang Yayasan
[11] Undang-Undang Republik Indonesia Nomor 28 tahun 2004 tentang Yayasan

[12]T. A. Shrimp, Periklanan Promosi dan Aspek Tambahan Komunikasi Pemasaran.Terpadu, Jilid I (edisi 5), Jakarta: Erlangga. 2003.

[13] K. Clow dan D. Baack, Integrated Advrtising, Promotion, and Marketing Communication. New Jersey: Pearson. 2010.

[14]P. Kotler dan K. L. Keller, Marketing Management, 14 ed Pearson Education, Inc., publishing as Prentice Hall, One Lake Street. 2012.

[15]N. J. Setiadi, Perilaku Konsumen: Konsep dan Implikasi untuk Strategi dan Penelitian Pemasaran, Jakarta: Prenada Media. 2003.

[16]E. Lip, Desain dan Feng Suhi: Logo Merek Dagang dan Sign Board. PT Alexmedia Komputindo. Jakarta. 1996.

[17]D. E. Carter, The Big Book of Logos 4 (no.4) Collins Design. 2005

[18]P. Kotler dan K. L. Keller, Marketing Management, 15th Edition, Pearson Education,Inc, 2016.

[19]D. Zarella, The Social Media Marketing Book. USA: Oreilly Media. 2010.

[20]M. Ahmed dan Z. Zahid, Role of Social Media Marketing to Enhance CRM and Brand Equity in Terms of Purchase Intention. Asian Journal of Management Research, 4(3), 533-549. 2014.

[21]E. Pane, Tingkat Adopsi Media Sosial Sebagai Sarana Pemasaran Produk Industri Kecil dan Menengah. Jurnal Penelitian dan Pe- 
ngembangan Komunikasi dan Informatika. 5(1), 1-15. 2014.

[22]R. Thackeray, B. Neiger, C. Hanson, dan J. McKenzie, Enhancing Promotional Strategies Within Social Marketing Programs: Use of Web 2.0 Social Media. Health promot Practise, 9(4), 338-343. 2008.

[23] W. Mangold dan D. Faulds, Social Media: The New Hybrid Element of the Promotion Mix. Business Horizons, 357-363. 2009.

[24]P. Kietzmann, K. Hermkens, I. McCarthy, dan B. Silvestre, Social Media? Get Serious! Understanding the Functional Building Blocks of Social Media. Business Horizons, 54(3), 241-251. 2011.

[25]P. Berthon, L. Pitt, K. Plangger, dan D. Shapiro, Marketing Meets Web 2.0, Social Media, and Creative Consumers: Implications for International Marketing Strategy.
Business Horizons, 55(3), 261- 271. 2012.

[26]J. Lu, J. Yao, dan C. Yu, Personal Innovativeness, Social Influences and Adoption of Wireless Internet Services via Mobile Technology. The Journal of Strategic Information Systems, 14(3), 245- 268. 2005.

[27] N. Michaelidou, N., Siamagka, dan G. Christodoulides, Usage, Barriers and Measurement of Social Media Marketing: An Exploratory Investigation of Small and Medium B2B Brands. Industrial Marketing Management, 40(7), 1153-1159. 2011.

[28] https://www.tahupedia.com/content /show/789/10-Sosial-Media-PalingBanyak-Digunakan-Di-Indonesia diakses tanggal 9 Nopember 2019.

[29] https://databoks.katadata.co.id/data publish/2018/02/01/media-sosialapa-yang-paling-sering-digunakanmasyarakat-indonesia diakses tanggal 9 Nopember 2019. 